\title{
BIOECOLOGICAL DEVELOPING PECULIARITIES OF MELON FLY AND CONTROLLING ACTIONS
}

\author{
Toreniyazov Elmurat Sherniyazovich ${ }^{1}$, Yusupov Rysnazar Orazbaevich ${ }^{2}$, \\ Eshmuratov Elbrus Gaybullaevich ${ }^{3}$ \\ ${ }^{I} D S c$ in Agricultural Sciences, Professor \\ ${ }^{2} \mathrm{PhD}$ in Agricultural Sciences, Associate Professor
}

${ }^{3} \mathrm{PhD}$ in Agricultural Sciences, Karakalpakstan Institute of Agriculture and Agrotechnology

Article DOI: https://doi.org/10.36713/epra9078

DOI No: $10.36713 /$ epra9078

\begin{abstract}
The article describes the development of biological and ecological features and harmfulness of melon fly on crops of melons in conditions of Karakalpakstan. It is studied the efficiency of the deep autumn plowing of soil against overwintering pests, special traps to kill the larvae and pupae, chemical treatments against the imaginal phase melon fly on crops of melon. The impact on the conservation of wild melon pest overwintered individuals. Recommended optimal protective measures in extreme conditions of Karakalpakstan.

KEYWORDS. Melon fly, melon, pest, biological, chemical treatment efficacy.
\end{abstract}

\section{INTRODUCTION}

The territory of Karakalpakstan is situated in the western part of the Republic of Uzbekistan, the weather condition is sharply continental with an extra arid climate. In recent years, in this condition from vegetables - average and late ripening types of melon, watermelon, and pumpkin are being planted to 6000-6189 hectare field. Every year 100.6-104.2 thousand tons of products are produced and used as food.

It was shown that the norm of eating vegetables for human is $19.3 \mathrm{~kg}$ as other agricultural products on the basis of medical norm in order to be healthy. For this, today for 1875.0 people 36187.5 tons of products should be delivered. In this case, there are some unfavorable factors which influence on increasing productivity of sowing vegetables, producing qualitative product. One of these issues is grouping different types of sucking and rodent pests in vegetable growing fields during the period of vegetation and bringing into the decrease of productivity. Today the most dangerous pest of vegetables is melon fly - Myiopardalis pardalina Big, mainly damages the fruit. Works of scientists, who carried out scientific researches about the appearing center of the pest, spreading areas, morphological structure, bioecological developing peculiarities and dynamics, the degree of damage, controlling actions were studied [2; 25-26-p., 7; 73-77-p., 11; 46-48-p., 15; 517-519., 16; 3-16., 23; 14].

It was determined that melon fly type Myiopardalis pardalina Big has spread in vegetable fields of the Republic of Karakalpakstan since 2001, and today's actual problem is its degree of damage, morphobiological structure and organizing controlling actions.

\section{METHODS OF THE RESEARCH}

In the conditions of Karakalpakstan, methods of sowing vegetables, agrotechnical actions, which were carried out during the vegetation period, intercrop plowing, irrigation, fertilizing, harvesting yield were carried out with the help of the methods accepted in the local conditions [24; 54-74-p., 3; 129-174-p., 13; 


\section{EPRA International Journal of Research and Development (IJRD)}

96-p.].

In order to study influence of abiotic factors on the development of melon fly in the local conditions, air temperature, moisture and the precipitation rate were analyzed by the information of the meteostation in Chimbay.

Small experiments were conducted in the laboratory of plant protection of Karakalpakstan institute of agriculture and agrotechnologies to analyze and defining pest morphology. In laboratory conditions determining body structure, indicators, developing phases, morphological indicators of melon fly was carried out according to the methods of V.B.Golub [6; 228-p.] by enlarging 20-100 times with the help of the special binocular microscope.

Samples of pests were taken from 20 places of the field (50x50x30 cm scheme) and placed in a special insectarium to study the conditions of wintering, and in the spring observation was carried out by digging the soil according to the special method of Sh.T.Xujaev [20; 12-p.]

In studying the developmental phases, dynamics, bioecological developmental differences of melon fly in the fields of vegetables of the Republic and creating phenogram methods of A.N.Kojanchikov [12; 286-p.], B.V.Dobrovolskiy [8; 231-p.], E.A.Dunaev [10; 44-p.], K.K.Fasulati [19; 231-p.], V.F.Paliy [14; 189-p.] were used.

On the $1 \mathrm{st}, 3 \mathrm{rd}, 7 \mathrm{th}, 14 \mathrm{th}$, and $21 \mathrm{st}$ days before and after the application of the insecticide against the adult phase of the melon fly, the number of pests was determined by examining 100 plants. Observations in both standard and control variants during the period of controlling were conducted on the basis of the methods of K.A.Gar [4; 167-p., 5; 142-p]. Biological efficiency was defined by the formula of W.S.Abbot [22; 265-267-p.]. With the help of B.D.Dospexov's [9; 340-p] method, mathematical and statistical analysis of the data obtained was conducted, samples were selected and variants were placed.

\section{RESULTS OF THE RESEARCH}

In the observations for fulfilling aims and tasks of the research it was taken into consideration that melon fly type - Myiopardalis pardalina Big is from the species of black and white winged - Tephritidae family, its worms eat vegetable fruits and according to the feeding it is considered to be oligophage.

According to the morphological features of the melon fly, the oral apparatus is juvenile on adults, the eyes are green or light green, and they belong to the opposition type, which is prone to daytime vision. There is a excrescence in the abdomen of the female pest, which helps to adapt to copulating and laying eggs on the fruits of vegetables. The breast is yellowish and covered with small hairs. On the upper side of them there are two ventages, and on the outer side there is a sign covered with white stripes. The abdomen was brownish-yellow and slightly larger than the chest. The wings have clear visible lines drawn in sections. Their inner two calves are arranged in a V-shaped form on both sides.

The average body length of adults was studied according to the morphological structure of each offspring of melon fly in the regional conditions. In this case, the average body length of pistils in the first generation was $5.9 \pm 0.11 \mathrm{~mm}$, in paternities $5.3 \pm 0.08 \mathrm{~mm}$, in the second generation $-5.7 \pm 0.06$ $\mathrm{mm}$, and $5.1 \pm 0.06 \mathrm{~mm}, 5.9 \pm 0.04 \mathrm{~mm}$ and $5.5 \pm$ $0.08 \mathrm{~mm}$ in the third generation. The egg of melon fly is elongated, shiny white, about $0.35-1.0 \mathrm{~mm}$ long, and pistils lay eggs under the cortex of the fruit. The average length of the worms according to three generations, $9.1 \pm 0.21 \mathrm{~mm}$, white, and the legs are not well developed. The body of the worms is sloping towards the front, and in the last segment there are two small excrescences. The worms have welldeveloped oral organs, which they feed on and allow them to enter the soil. Due to the underdevelopment of the legs of the worms, they move with the help of the mouth organ by shinning.

The average length of the pest pupa is about $7.3 \pm 0.18 \mathrm{~mm}$ according to three generations, and it is passive in the soil. In this phase it changes into the phase of adult. The physical and mechanical properties of the soil are of great importance for the development of the pupa, and its structure, density, moisture, mechanical composition, temperature are of great importance in the physiological development.

According to the bioecology of the pest, each year, in the first ten days of June, it flies overwintering and makes groups in melon fields. It was found that overwintered adults copulated and after 2-3 days, when the size of the fruits was 3-4 cm, they began to lay eggs and cause damage. It is known that a pistil lays an average of 60-120 eggs during the life. In our experiments, egg laid fruits were collected and put into the bottom of the plants by using the special method of collecting worms and pupas of melon fly with the help of catching instruments. Within 3-4 days, the worms hatch from the fruits in which the eggs is placed, continue to grow and feed on the fruit, causing damage. The worms feed the fruits for 10-14 days, and then pierce the cortex and turns into pupa in soil conditions. It is taken into account that the pest has the ability to lay eggs in the soft tissues of the fruit cortex from $15 \mathrm{~cm}$ to $3 \mathrm{~cm}$ in size. After 14-18 days adult phases fly away from the pupa and gives a full three offspring during the growing season. During the course of our observations, it was found that the pupa had undeveloped adult phases. In our current experiments, it was found that the adults fly away in 8-30 days at a temperature of $25-30^{\circ} \mathrm{C}$ in the 


\section{EPRA International Journal of Research and Development (IJRD)}

conditions of open laboratory.

In the first ten days of June 2021, the number of melon flies began to appear in the melon fields, and in the second ten days the number of melon flies reached the maximum in the areas where no controlling actions were carried out. As mentioned above, the worms of the melon fly feed on the fruit for 14-18 days, then pierce the cortex and turns into pupa in soil conditions. Some worms turn into pupa in the fruit. The first worms pierced the fruits on July 8-10 during the period of our observations. It was found that the next generation flied away on July 2025. In most cases, controlling actions were not conducted to the generation in August and September. As a result of not controlling this generation, it leads to the emergence of melon fly in the next year.

The growth and development of wild melon, which is considered to be the main object in the subsequent spread, among different types of agricultural crops and near the fields, creates an opportunity to the development of melon fly generation. During our research, in most cases, in August-October, the fields of the wild melon were covered with melon fly, they lay eggs and the worms that hatched from them turned into pupa and were left in the soil that year. With this in mind, it is required to prevent the growth and development of wild melon among all agricultural crops, as well as near the fields.

It is considered to be effective to carry out controlling actions by studying the overwintering condition, peculiarities of morphological and biological development of the pest.

Taking into account the fact that the pest is one of the most fully developed insects, it was found out from the scientific research works that it is necessary to organize carrying out controlling actions in each phase. It is obvious that melon blossoms two or three times in the period of growth and development. It was proved that after using chemical preparations for prophylaxis in order to prevent adult melon flies from laying eggs, fruits should be placed to special protecting packets when their length is 8 $10 \mathrm{~cm}$.

As mentioned above, it is important to organize agrotechnical controlling actions in the wintering fields of the pupa of the third and fourth generations. In order to eliminate the wintering pupa, fields of agricultural crops were cultivated to a depth of $30-40 \mathrm{~cm}$ in the autumn, and then irrigated for saline washing. As a result of both autumn and spring agrotechnical actions, it was achieved to eliminate the wintering pupa of the pest.

When we use chemicals to control adults of melon fly, it should be used at the initial stage after the melon flowers have blossomed $70-80 \%$ and the fruits have formed. In this case, the recommended dose is $0.7-1.01 /$ ha of the preparation with deltamethrin $(25 \mathrm{~g} / \mathrm{l})$ and $0.4-1.01 /$ ha of the preparation with malathion $(570 \mathrm{~g} / 1)$ should be used per hectare at 5-8 in the morning, as well as preparations containing two active components, with chlorpyrifos (500 g / 1), cypermethrin (50 g / 1) 0.6$1.01 /$ ha, should be melted 200-300 liters of water in CSU-28 (Cotton sprayer universal-28) device and for small gardens it should be prepared for 100 or $10 \mathrm{~m}^{2}$ field by hand, using hand-held sprayers. As a result, the biological efficacy of the drugs used was 93.098.0 percent. The main reason for the use of preparations for adults in the morning is that the harmful adults are not in the flying state, and the fact that the preparations we use are in contact with each other. Depending on the variety of watermelon, it is recommended to use the chemicals during the growing season and two times before 20 days to collecting yield.

The peculiarity of the developmental bioecology of pests is that in late August, in September, the worms emerge from the fruits turn into pupa and overwinter at a depth of $10-20 \mathrm{~cm}$ in the soil. The following year, in order to prevent the increase of pests, the fruits and plants in the field and garden should be completely removed, the soil should be removed to a depth of $20-30 \mathrm{~cm}$, and irrigation works were carried out in September and October.

As a result, 90-95\% of wintering worm of melon fly are killed and the next year they will be prevented from manifolding. We recommend that these actions should be implemented by taking into account each region and farm.

\section{CONCLUSION}

It was determined that in the Republic of Karakalpakstan and in other regions, the only species that causes direct damage to vegetables is melon fly Myiopardalis pardalina Big member of two winged group. The pest fully gave birth to three off springs, and the fourth offspring winters in the pupa phase. It is expedient to organize integrated controlling actions to control the pest. The results show that the peculiarity of bioecological development of this species is that, the adult has the ability to fly in the air, both the egg and the worm will pass through the developmental phase in the fruit and pupas are placed in 5-20 cm depth of the soil. It is recommended that controlling the pest should be started from decreasing the number of wintering pupas, removing soil in 20$30 \mathrm{~cm}$ depth and using irrigational agrotechnical actions, using mechanical method to control worms and pupas in the vegetation period, using allowed chemical preparations to control adults and reaching to $95.0-98.0 \%$ of biological effectiveness. 


\section{EPRA International Journal of Research and Development (IJRD)}

\section{REFERENCES}

1. Adashkevich B.P. "Biological protection of cruciferous vegetable crops from harmful insects." - Tashkent: "FAN", 1983. p-180-188.

2. Asadov G.F. Melon fly // J. Plant protection. Moscow, 1963. -№2. p-25-26.

3. Buriev Kh.Ch. Melon growing. - Tashkent, 2002. p-129-174.

4. Gar K.A. Test methods for the toxicity and effectiveness of insecticides. - Moscow: "Agricultural literature, magazines and posters", 1963. $p$ - 167.

5. Gar K.A. Tests of the effectiveness of insecticides in natural and field conditions. - Moscow: "Kolos", 1967. p - 142.

6. Golub V.B., Kolesova D.A., Shurovenkov Yu.B. Entomological and phytopathological collections, their compilation and storage. Voronezh: "VU Publishing House", 1980. p-228.

7. Grishina E.N. Bioecological features of the melon fly in the conditions of Azerbaijan / Dokl. AN Azerb. SSR (T.20.). - Baku, 1964. - No. 8. p73-77.

8. Dobrovolsky B.V. Phenology of insects. - M .. Higher school, 1969. p - 231.

9. Dospekhov B.D. Field Experiment Technique (4th ed.). - Moscow: "Kolos", 1986. p- 25-340.

10. Dunaev E.A. Methods of ecological and entomological research. - M.: MosgorSYUN, $1997 . p-44$.

11. Isabekov B.B, Jamkeeva M.E. Ways of chemical control and spread of quarantine pests in the South Kazakhstan region // News of the National Academy of Sciences of the Republic of Kazakhstan. Agrarian Science Series 6 (24). Almaty, 2014. p-46-48.

12. Kozhanchikov I.V. Methods for studying the ecology of insects. - M.: Higher school, 1961 . p286.

13. Krzhivets L.S. Melons of Karakalpakstan. Nukus: "Karakalpakstan", 1977. p-5-6.

14. Paliy V.F. Methods for studying the fauna and phenology of insects. - Voronezh, 1970. p - 189.

15. Saparmamedova N.K. On the study of the melon fly Myiopardalina Big in Turkmenistan // Entomological Review. LXXXIII. - 2004. - No. 3. p- 517-519.

16. Tolikhov D.A. Features of growing melons in Tajikistan, yield and quality of fruits in irrigated conditions: Author's abstract. dis ... cand. agricultural sciences. - Dushanbe, 2016. p-3 - 16.

17. Toreniyazov E.Sh., Yusupov R.O. Features of the controlling melon fly in Karakalpakstan // J. Plant Protection and Quarantine. - Moscow, 2016. - No. 8. $p$ - 46.

18. Toreniyazov E.Sh., Yusupov R.O. Bioecology of species of two winged (Diptera) in Karakalpakstan agrobiocenosis, developmental differences. Monograph. - Nukus, «Karakalpakstan». - 2020.-8,0 b/t. p - 128.

19. Fasulati K.K. Ecology and economic importance of insects. - Leningrad, 1961. p-231.

20. Khojaev Sh.T. Guidelines for testing insecticides, acaricides, biologically active substances and fungicides (II edition). - Tashkent, 2004. p -102.

21. Yusupov R.O. Biology and harmfulness of the melon fly and the development of measures to control it. Abstract of Doctoral Dissertation in Philosophy of Agricultural Sciences. 06.01.09. Tashkent, 2018. p-20-25.

22. Abbot W.S. A method of computing the effectiviness of an insecticide //J. Econ. Entomol. - 1925. - V.18. - №3. p-265-267.

23. Baris A., Cobanog'lu S. Kavun Sinegi [Myiopardalis pardalina (Bigot, 1891) (Diptera: Tephritidae)] nin Farkli Kavun Cesitlerindeki Zarar Oranlarinin Belirlenmesi /Proceedings of the fourth plant protection congress of Turkey. Kahramanmaras, 2011. $p-14$.

24. Ibragimov M. Vegetables. - Nukus: «Bilim», 2012. $p$ - 54-74.

25. Stonehouse J., Sadeed S.M., Harvey A., Haiderzada G.S. Myiopardalis pardalina in Afghanistan /Fruit Flies of Economic Importance: From Basic to Applied Knowledge Proceedings of the $7^{\text {th }}$ International Symposium on Fruit Flies of Economic Importance. - Brazil, Salvador, 2006. - P. 1-12. 